\title{
Drowning the Greek economy: Injurious speech and sovereign debt
}

\section{Faye Donnelly}

University of St Andrews, UK

\section{William Vlcek}

University of St Andrews, UK

\begin{abstract}
Drawing on Judith Butler's concept of injurious speech, this article conceptualises the 'Grexit' crisis as a series of performances. More specifically, we investigate how the Greek government framed the bailout plans tabled by the Troika as a form of torture. By adopting phrases such as 'fiscal water-boarding', 'asphyxiation', and 'suicide', the Syriza government sought to narrate the harm inflicted on Greece by its creditors. Paying attention to this language is important as it casts new light on how Greek sovereign debt has been framed, negotiated, and contested. In many ways, the overarching objective of this article is to tell a different story that takes discursive transitivity and restaging into account. By shifting the emphasis onto injurious speech, the article also brings the unintended effects of this language into focus. Despite the recurrent accusations made by Syriza as it attempted to resolve the Greek sovereign debt crisis, this article questions whether their bargaining strategy 'misfired'. On closer consideration, we find that the injurious speech acts performed by the Syriza government compromised their ability to negotiate a third bailout deal in 2015 . The observations remind us that words can wound in ambivalent ways.
\end{abstract}

\section{Keywords}

Injurious speech, sovereign debt crisis, Syriza, fiscal waterboarding, the Troika, compromise

\section{Introduction}

In January 2015 the Syriza party came to power in Greece under the charismatic leadership of Alexis Tsipras (Financial Times, 2015b; Wagstyl and Bryant, 2015; Varoufakis, 2012; Yardley et al., 2015). Drawing on Judith Butler's concept of injurious speech, this article conceptualises

\section{Corresponding author:}

Faye Donnelly, School of International Relations, University of St Andrews, St Andrews, Fife KY16 9AX, Scotland, United Kingdom. Email: fd47@st-andrews.ac.uk 
the negotiating strategy adopted by the incoming government to tackle debt repudiation as a series of discursive performances and situated entanglements. More specifically, we investigate how Tsipras and his administration framed the existing bailout plan tabled by the Troika as a form of torture by adopting phrases such as 'fiscal water-boarding', 'asphyxiation' and 'suicide'. ${ }^{1}$ Although the recurrent accusations punctuating Syriza's bid to resolve the Greek sovereign debt crisis sought to enhance its bargaining position and apportion blame onto their creditors, we raise the question of whether this strategy 'misfired'. As is shown, the series of injurious speech acts performed by the Greek government made it extremely difficult for a compromise to be reached when it came to negotiating a third bailout deal in $2015 .^{2}$

The negotiating stance enacted by Syriza during this time period is important for three reasons. First, while existing scholarship has provided important insights into the ways in which the Greek sovereign debt crisis has continued to unfold (Welfens, 2016; Moschella, 2016; Featherstone, 2011), the language of torture, fiscal waterboarding and asphyxiation is often overlooked. Instead, many scholars emphasise the structural limitations to Eurozone financial governance. This line of argument, for example, has led Paul Welfens (2016) to offer proposals to reform the European Union (EU). Elsewhere, Manuela Moschella (2016) explores the evolution of economic crisis management mechanisms at the European Central Bank (ECB) in reaction to the Greek sovereign debt crisis, using these to explain the differences between the first and second Greek bailout programmes (see also Ardagna and Caselli, 2014).

Second, a number of other scholars have taken the 'Greek case' as a starting point to explore ways in which the Eurozone crisis was "enacted in discourse" (Wodak and Angouri, 2014: 419). Without having to fully agree that "small stories research" provides a "microperspective for the scrutiny of any crisis-related positioning of 'Greece' and 'the Greeks'" (Georgakopoulou, 2014: 519), it is hard to deny that "further linguistic research is needed to unpack how crises are negotiated" (Wodak and Angouri, 2014: 419). Scholars studying the language of blame and punishment in the Greek economic crisis appear to have answered this call. They have been at the forefront of documenting 'indignados' in the Greek polis over the origins and responsibilities of the Greek crisis (Aslanidis and Marantzidis, 2016; Theodossopoulos, 2013). Georgios Karyotis and Wolfgang Rüdig (2015) also examine the impact of a domestic economic policy of austerity in the electoral politics of Greece through a 'securitization' lens. According to their account, the Greek government sought to legitimate the use of extreme measures in 2010 to prevent the national economy from being existentially threatened. Alternatively, Radman Selmic (2016) has cast the ECB as a strategic player in the blame game that ensued between the Troika and the Greek state.

At first glance, the extensive negotiations that took place between the Syriza government and what they later termed the 'institutions' and their European 'partners' appear to fit neatly into the logic of a complex blame game on the one hand, and even a securitization process on the other. ${ }^{3}$ However, these accounts cannot explain how the Grexit crisis was narrated through the language of compromise. Taking this consideration on board in the context of the Greek sovereign debt crisis, we show that it is crucial not to overlook the fact that interlocutors on all sides of the table repeatedly deployed the language of European solidarity and trust. Upon entering office, for example, Yanis Varoufakis, the new finance minister, stated "There won't be a duel between us and the EU ... There won't be any threats" (quoted in Hope et al., 2015a). At later stages of these deliberations, certain delegates from the Greek government and the Troika also appealed for an end to the "toxic blame game and the moralising finger-pointing" enveloping these talks (Wearden and Fletcher, 2015). ${ }^{4}$ In this light, there is nothing inevitable about the Syriza government adopting injurious speech or securitizing logics to prevent Greece from being suspended from the Eurozone. The point here is not to argue that the language of 
blame or securitization is completely absent in this case. Nonetheless, we contend that more research is needed to understand how the language adopted by members of the Greek government is injurious, rather than presuming automatically that their words wounded the Troika or vice-a-versa (Adler-Nissen, 2017). This article is an initial step towards this goal.

Third, conceptualising the 'Grexit' crisis through the lens of injurious speech connects to an overarching concern of those studying the performativity of economics and crisis (Aitken, 2007; Esposito, 2013; Langley, 2015; MacKenzie, 2004; MacKenzie, 2007; MacKenzie, 2008; Roscoe, 2016). The emphasis of this literature is very much on engaging with Donald Mackenzie's (2004: 328) question, "what sort of world do we want to see performed?" While the notion of performativity adopted in this article is very much inspired by these debates, we suggest that the concept of injurious speech is worthy of further consideration. Tellingly, Butler (2010) herself does not fully sketch out the relationship between injurious speech and economic practices. In this spirit, we suggest that injurious speech may denote a particular category of performativity. As will be shown, these types of performatives are important for understanding the oscillations that emerged in the Syriza government's bargaining position as the negotiations unfolded. What gradually becomes more apparent is how "a game is never over, for new framings are always possible" (Callon, 2007: 321).

To analyse the Greek sovereign debt crisis as a form of injurious speech, we trace the varied discourses espoused during the intensive window of negotiations that opened up between January and August 2015. Informed by an in-depth analysis of publicly available material, ranging from newspaper articles to press releases and academic blogs, our study starts from Butler's premise that we never know in advance which words injure. In short, we take a critical step back to examine which words wounded and how. To capture the ambiguity of the injurious and counter- speech used in this context, moreover, we do not simply investigate the dominant articulations performed by key members of the Syriza government or the Troika. In parallel, we study how these utterances were framed, circulated and communicated by a number of international English-language media outlets.

The remainder of the article proceeds in four steps. The first section outlines the concept of injurious speech and its performative potential. From here the next two sections offer an empirical analysis of the intense period of negotiation that unfolded between the Syriza government and its bailout creditors from January to August 2015. Finally, the article concludes with an invitation for critical scholars to continue to explore how words wound in ambiguous ways.

\section{Injurious speech and linguistic vulnerability}

Judith Butler's concept of injurious speech has a close kinship with the work of J.L. Austin (1975). Assuming that 'words do things', she provides a complex reconsideration of the violence created by and enacted through different modalities of speech. Whilst physical acts of violence are often the most visible, Butler demonstrates that forms of linguistic violence (such as sexual harassment, bullying, and hate speech) have detrimental emotional and psychological effects on individuals. All too often these acts of violence are overlooked, ignored, unrecognised or unheard. These dilemmas provide the immediate backdrop to Butler's (1997: 6) investigations into "the injury that language itself performs". By introducing the concept of injurious speech, she aims to tackle anew the performativity of words and to reassess how power operates through discourse. In her account words that wound are actions. However, "not all name calling is injurious" (Butler, 1997: 2). 
From the outset, Butler (1997: 3) acknowledges the inherent difficulties of neatly delineating the boundaries of any "total speech situation". Instead she encourages us to examine the "complexity of the performative terrain" (Butler, 1997: 16). Unpacking the layers of speech operating within any linguistic field highlights that they are "ones of enabling constraints from the outset" (Butler, 1997: 16). In this sense, the origins of the dominant narrative are already established. Consequently, no single word is completely sovereign. In tandem, Butler cautions against predetermining the kinds of injuries people can and will express and the types of vocabulary they will adopt in the process (see also Butler, 1993, 2010). She also leaves room for ambiguity surrounding who is assigned blame and held accountable for the offensive utterance.

Although Butler does not diminish the power of words to inflict pain or to generate hatred, her account of injurious speech correctly reminds us that language is always a site of negotiation and contestation. Honing in on the "vulnerability of language to failure" is essential for Butler (1997: 12). It enables her to make a case for counter-speech, which she describes as a kind of "talking back" (Butler, 1997: 19, 50). At base, Butler portrays counter-speech as an unexpected outcome since it constitutes an enabling response in the face of linguistic injuries. Introducing this idea of counter-speech suggests that even the most venomous injuries enacted through words can 'misfire' (Austin, 1975; Åtland and Ven Bruusgaard, 2009; Butler, 2010; Callon, 2010; de Goede et al., 2014). This misfiring can happen in several ways. For starters, any speech act performed may solicit an unintended response. As Butler (1997: 11) notes,

a threat can be derailed, defused, can fail to furnish the act that it threatens. This failure to deliver on the threat does not call into question the status of the speech act as a threat - it merely questions its efficacy.

Given that any speech act can be countered by a different kind of performative, the original utterance can always be "returned to speaker in different form" (Butler, 1997: 14). In the same capacity, "the speech act says more, or says differently, than it means to say" (Butler, 1997: 10). Once again, these points raise the possibility that our words have unexpected outcomes and a discursive transitivity (Butler, 1997: 47). In effect, this pushes us beyond the confines of the speech act alone.

A key thread woven through Butler's discussion is that performativity is a repetitive doing rather than a single action. Consequently, she presents injurious speech as "ways of restaging" (Butler, 1997: 20). What is at stake here is the ability of agents to recall prior acts and past practices so as to wield performative power to injure others. Since terms carry past connotations they come to gain an "accumulative force of authority" (Butler, 1997: 51, emphasis in original). Taking this insight on board reaffirms how words that injure are "not a series of discrete speech acts but a chain of resignification whose origins and end remain unfixed and unfixable" (Butler, 1997: 14). In other words, injurious speech acts never exist in isolation to the wider contexts in which they are performed and ritualistically repeated.

Butler's concept of injurious speech parallels broader discussions of the performative sites of iteration that "attend to the political uncertainties, contestations and misfires" (de Goede et al., 2014: 417). It also overlaps with approaches and theories that have placed performativity on the agenda of economics studies. These diverse agendas pivot on the idea that agency is "performed in a variety of sites and situations" (Callon, 2007: 329). They also tend to focus on the performativity of markets and non-human assemblages. As Michel Callon (2007: 319) observes, the term agencement "conveys the idea of a combination of heterogeneous elements that have been carefully adjusted to one another". Elsewhere, Rob 
Aitken has claimed performativity on the part of 'capital'. As he shows, capital is "made real in its everyday performances" rather than existing as a factor already present and operating in the economy (Aitken, 2007: 11). These everyday actions, in turn, afford the government a means of guiding and controlling the economy through measures encouraging or discouraging forms of savings and investments available to citizens (Aitken, 2007: 68-70). In the case of Greece, we see these everyday financial practices embedded in patterns of capital flight that followed the election of the Syriza government and its subsequent imposition of capital controls (Stamouli, 2017).

Within this growing set of literature, performativity is used to refer to many things (Esposito, 2013; MacKenzie and Millo, 2003; Muniesa, 2014; Roscoe, 2016). According to Donald MacKenzie, for example, there are at least two different types of performativity. For our purposes, what is important is that these debates often extend to include counterperformativities (MacKenzie, 2004: 306) and overflowings (Callon, 2007; Callon, 2010). In this vein, Callon (2010: 164) proposes that we study "the notion of performation alongside that of the co-performation struggle". From this perspective, performativity and misfires are not in tension or collision. On the contrary, "the general rule is misfire" (Callon, 2010: 164). It is precisely this point that Butler makes when she discusses how performativity works in relation to economic practices. Indeed, she contends that "fallibility is built into the account of performativity" (Butler, 2010: 152).

Following Donald MacKenzie (2004), this article does not seek to resolve these entrenched debates. Instead, we contribute to them by conceptualising injurious speech as a mode of performativity and counter- performativity. Surprisingly, whilst many of these authors engage with Butler's work, they do not make the concept of injurious speech a driving category of their analysis. More problematically, Butler herself does not explicitly sketch out how injurious speech functions in economics. Hence, while the possibility of failure and restaging is omnipresent in both sets of literature, little attention has been paid to how performatives and overflowings can be injurious in nature. Pondering on these understudied connections raises all sorts of interesting questions and future lines of research. How do agents enact injurious speech in economics? Is this language always reserved for times of crisis? If injurious speech operates through accumulative force, then from where does this originate? If injurious speech is always subject to misfire, failure and contestation, then why do actors invoke it? What happens if multiple actors perform injurious speech simultaneously? Who decides if a linguistic performative is injurious? Can counter-speech be performed through the enactment of injurious terms?

To shed light on these questions, the next two sections explore how the Syriza government restaged the bailout agreement as an injury inflicted on the Greek economy and people. Going a step further, we examine their injurious speech as a form of counter-speech ritualistically repeated to speak back to the Troika. As is shown, this bargaining strategy produces a tangled web of unexpected outcomes, discursive shifts and misfires. Hence, when applied analytically to the Greek sovereign debt crisis, injurious speech shines a specific spotlight on how 'Grexit' was avoided and an agreement was reached in 2015.

\section{Stop Greece bleeding: Scenes of injurious counter-speech}

From the outset, it is important to note that Syriza is not the originator of this discourse. Its rhetorical stance is firmly rooted in the anti-austerity 'redlines' they drew before coming into power. As a political force, Syriza is a product of the economic crisis afflicting Greece and 
reshaping its political economy since 2010. To situate Syriza as a 'force', rather than as a 'party', acknowledges its origins "as a coalition of a number of rather insignificant left-wing formations" in Greek politics (Nikolakakis, 2016: 128). Syriza first gained widespread recognition during the two Greek general elections of 2012 by presenting a "left-wing populism" to challenge the austerity policies undertaken by the incumbent government (Stavrakakis and Katsambekis, 2014). Notably, Yanis Varoufakis first used the term 'fiscal waterboarding' in 2012 (see Varoufakis, 2012).

What is also apparent is that Syriza was significantly constrained by the existing bailout agreements negotiated by previous Greek governments. Making this plain even before Syriza came into power, the German Finance Minister, Wolfgang Schäuble, warned that "new elections change nothing [...] Any new government must stick to the contractual agreements of its predecessors" (quoted in Galbraith, 2016: 50; BBC News, 2014). At the annual meeting of the World Economic Forum in Davos, the Greek government was told that it must "[hold] to its prior commitments" (Forelle, 2015). The veiled threat encapsulated in these speech acts was that the situation could become very difficult if Greece decided to pursue a different set of options. As James K. Galbraith (2016: 59) notes, Athens "faced an immediate need for new financial terms" with which it could simultaneously speak to their supporters and their creditors.

Although Tsipras and his cabinet placed some of the responsibility for the financial woes facing their country on the shoulders of the previous Greek government, they reserved their harshest criticisms for the Troika (Walker, 2015). In this sense, the injurious speech acts uttered by the Syriza government exhibit a mode of counter-speech rather than a linear blame game. Put differently, we argue that the standoff that Athens pursued with the Troika between January and August 2015 can be conceptualised as a series of performances in which they sought to deploy linguistic power to talk back to what they perceived to be "the accountable originator of an injurious deed" (Butler, 1997: 45-46). When examining the main plot line espoused by the Syriza government, this message is actually quite clear. As Varoufakis maintained, "We have no intention of co-operating with a three-member committee whose goal is to implement a programme whose logic we consider anti-European" (quoted in Trotman, 2015).

Injurious words were wielded more explicitly as a deliberate campaign of counter-speech in February 2015, as Syriza requested an extension to the bailout agreement it had vehemently opposed from the outset. Speaking about procedures tabled at this time, Varoufakis warned that "They are trying to asphyxiate us with arbitrary deadlines" (quoted in Evans-Pritchard, 2015b). Hinting at the looming threats, he also noted the following:

The euro is fragile. It is like a house of cards. If you pull away the Greek card, they all come down [...] Anybody who is tempted to think it possible to amputate Greece strategically from Europe should be careful. (Varoufakis, quoted in Evans-Pritchard, 2015a)

The Eurozone and IMF creditors strongly denied these confrontational remarks. As Pierre Moscovici, the European Commissioner for Economic and Financial Affairs, noted, "There is no good-cop, bad-cop game" (quoted in Spiegel, 2015b). Taking a more sceptical stance, Schäuble quipped, "Do they have a plan? [...] None of my colleagues so far understands what Greece wants [...] whether Greece itself knows what it wants is not clear either" (quoted in Paterson and Savaricas, 2015).

Confronted with the prospect of finding itself without an EU financial backstop, the Syriza government submitted a request to continue under the bailout programme (Galbraith, 2016: 
58; Spiegel et al., 2015b). In a letter to the Eurogroup, Varoufakis asked for an additional six months to bring the programme to a successful conclusion (Spiegel et al., 2015b). Although this letter marked a dramatic reversal of the Syriza government's pledge, it was rejected by Berlin as a 'Trojan Horse' (Spiegel et al., 2015b; Ayiomamitis, 2015). For many Greeks, the tough stance adopted by the Troika in this instance illustrated that Schäuble was "thirsty for blood" (Ayiomamitis, 2015). For others, "the cool response to the letter from the other two creditor institutions in what Greece no longer wants to call the 'Troika' - the International Monetary Fund and the European Central Bank - highlights how much trust has been damaged in the course of fractious negotiations" (Financial Times, 2015a).

In a climate of great uncertainty and mounting tensions, the Syriza government went to Brussels to discuss the full range of economic issues. On 20 February, after three crisis meetings, they were given a temporary lifeline when it was agreed that Greece would be given extra time to complete the bailout agreement and receive the remaining 7.2 billion euros. An important clause at the centre of this provision, however, was that the country would not be allowed any funds until it passed a review that could take weeks to negotiate and finalise. The extension of the pre-existing bailout programme also included a requirement that the Syriza government would provide the institutions with a list of reform measures to be implemented going forward. Further negotiations would refine this list, with the goal of having this approved by the institutions before the end of April 2015. In the interim, Schäuble warned that Greece would not receive "a single euro" until it satisfied the pledges of its existing bailout programme (Anderson, 2015). On this occasion he also stated that "if the Greeks violate the agreements, then they have become obsolete" (Anderson, 2015).

Taken together, the concessions made by the Troika in February 2015 were predominantly framed as the infliction of another humiliating injury onto Greece. As Michael Jacobides (2015) wrote, "For all of its bravado, Greece was pushed into a corner in an eleventh-hour deal that will extend a bailout agreement for four more months ... [but] little has been resolved". Elsewhere it was concluded that the new government faced "a rude awakening ... when German-led pressure forced it to pedal back on most election pledges in the face of national insolvency" (Petrakis, 2015). Yet perhaps a more helpful way of gleaning insights into the intensive crisis talks that took place in Brussels is to return to Butler's (1997: 16) insight that all performative utterances are "ones of enabling constraints from the outset". Doing so reminds us that a choice over how to continue the loan agreements had to be made by 28 February 2016. As such, "there was never any chance for a loan agreement that freed Greece's hand" (Galbraith, 2016: 62).

Conceptualising this stage of the negotiations as a site of injurious speech, moreover, highlights that Syriza did not yield on its promise to end austerity. Conversely, they continued to counter what they perceived to be outstanding injuries. Although the Greek government was unsatisfied with the outcome of the February negotiations, their defiant calls for debt relief were crucial in enabling them to pursue 'an honest compromise' throughout the remainder of the negotiations (Paterson and Savaricas, 2015; Evans-Pritchard, 2015d; Jamieson, 2015). Tellingly, Tsipras later framed the outcome of these crisis meetings as "an important step. A decision was made to give us breathing room" (quoted in Ertel et al., 2015). The use of 'breathing room' within this account reinforces the powerful role counter-speech played in Syriza's bargaining strategy. Whilst acknowledging that Greece had been given some leeway, Tsipras still subtly invoked and ritualistically repeated the charges of asphyxiation, strangling and waterboarding his government had made against the Troika. Adopting a more severe outlook on the bailout extension granted to Greece in February 2015, Varoufakis maintained "We have averted many years of suffocating primary surpluses that would destroy our 
industrial base" (quoted in Evans-Pritchard, 2015c). In this way, a campaign of counter-speech re-emerged to challenge and contest ongoing suggestions that Greece had succumbed to the whims of their creditors. Indeed, Tsipras maintained that Athens "had won the battle, not the war" (quoted in Stevenson, 2015).

\section{Breathing under water? Countering the asphyxiation of Greece}

Syriza continued to implement a forceful campaign of counter-speech against the bailout agreements, the Troika and the financial asphyxiation of Greece until the terms of the third bailout agreement were settled in August 2015. No matter how dire the situation got, Tsipras ritualistically repeated that his country would continue to breathe even as its economy was being drowned. In order to restage the possibility of Greece defaulting on their outstanding debt payments as a mode of resistance rather than a form of weakness, Syriza relied heavily on a narrative of relentless pain being inflicted on the Greek people.

Underscoring the financial constraints experienced by the Greek government as it attempted to stabilise the economy in this environment, Tsipras told Der Spiegel that the ECB was "still holding the rope which we have around our necks" (quoted in Khan, 2015a). Several days later, Varoufakis continued this analogy of strangulation when he accused the ECB of "pursuing a policy that can be considered asphyxiating toward our government" (quoted in Khan, 2015c). In order to silence these accusations, the head of the Bundesbank declared that the Greek government had "squandered the trust of its European partners" (quoted in Khan, 2015c). Shortly after this statement, Tsipras sent a letter, dated 15 March 2015, to Angela Merkel, the German Chancellor, warning that it would be "impossible" for the Greek government to make its next scheduled debt repayments without either a distribution from the bailout fund or issuing additional short-term debt (quoted in Spiegel, 2015a).

Notably, as their use of injurious counter-speech intensified from March to July 2015, the language of terrorism, fiscal waterboarding and criminal responsibility were increasingly interwoven into a discursive cluster. A primary logic of this narrative stance was to severely challenge moves undertaken by the Troika to present their position as fair, patient and tolerant (Spiegel et al., 2015a; Sheffield, 2015). These competing modes of performativity made it extremely difficult to reach an agreement on the list of revenue measures to satisfy the institutions. In a parliamentary address at the end of March 2015, Tsipras declared that the government would not agree to an increase in VAT. Instead, he promised to stop "the Greek people's bleeding" (quoted in Khan, 2015e). However, rather than wavering on their call for a VAT increase, the representatives of the institutions pushed for further reductions in the government's pensions and wages bill. A prolonged stalemate in the deliberations between Syriza and the Troika ensued. Describing the situation at the Brookings Institution in Washington, DC, in April 2015, Varoufakis declared that the Troika were attempting to control Greece through "liquidity asphyxiation" (quoted in Evans-Pritchard, 2015e). By constraining the availability of short-term capital to Greek banks, the ECB was effectively constraining the entire Greek economy. Schäuble, who also was speaking at the Brookings Institution, dismissed this line of argument. Responding to the harsh criticism made by Varoufakis, he insisted that Greece must fulfil the obligations of the memorandum because "we will not help a country that refuses to help itself" (quoted in Evans-Pritchard, 2015e).

As Syriza continued to battle with the Troika over how to keep their economy afloat in order to avoid 'Grexit', they continuously used injurious speech to address their domestic audiences. To borrow from Marieke de Goede's (2015: 357) analysis of courtroom contestations, it is clear that their injurious speech sought to create an alternative benchmark 
for valuation. By reasserting that Greece would not compromise in the face of what Panagiotis Lafazanis called "the bogeyman of default and a national currency" (quoted in Khan, 2015d), the Syriza government openly worked to frame their negotiation stance as a matter of national dignity, pride and sovereignty.

For example, in May 2015, at the apex of the crisis, Tsipras restaged accusations that Greece was deploying an "intransigent, uncompromising and incomprehensible" stance (quoted in Spiegel, 2015c). Talking directly back to the bailout monitors, he maintained that the root cause of the growing dilemma was "the insistence of certain institutional actors on submitting absurd proposals and displaying a total indifference to the recent democratic choice of the Greek people" (quoted in Spiegel, 2015c). As the Greek economy continued to plummet, the Syriza government continued to actively frame the bailout as a deliberate form of humiliation inflicted on their country (Spiegel and Hope, 2015). In this way, the bailout was narrated as "illegal, illegitimate and odious" (BBC News, 2015).

Weaving these performances together takes us closer to understanding how a popular referendum on the question of whether to reject a compromise with international creditors became possible by July 2015. In late April 2015, Tsipras stated in a Greek television interview that "I have not decided for a referendum, let's be clear. I am answering to a hypothetical question" (see Papamiltiadou, 2015). Nonetheless, by this stage of the sovereign debt crisis, it was plain that a referendum would be necessary to affirm any agreement with the Troika since it conflicted with Syriza's electoral mandate. At this point, it is also worth recalling Butler's claim that injurious speech operates through accumulative force and historical contexts. A referendum regarding the parameters of a second bailout agreement was first proposed by Prime Minister George A. Papandreou in 2011. Three days later, this proposal was shelved after it had "whipsawed world markets", according to the New York Times (Donadio and Kitsantonis, 2011). Crucially, the act of proposing a popular vote on the agreement angered other members of the Eurozone, leading one observer to assert that for this "temerity he [Papandreou] was summoned to Cannes by Angela Merkel and Nicolas Sarkozy; the referendum was cancelled and Papandreou was destroyed" (Galbraith, 2016: 7, fn. 7).

It is here that Butler's conceptualisation of a chain of extended doings makes another important contribution. Inspired by this outlook, we can detect a change in the discursive terrain. Whilst 'Grexit' was perceived by the Troika as an existential threat to be avoided at all costs in 2011, four years later many powerful actors in Europe believed that the Eurozone could survive, and even thrive, in this kind of scenario. Hinting at his openness to Greece leaving the Eurozone, Schäuble suggested that it could "be a helpful measure for the Greek people to decide whether it is ready to accept what is necessary, or whether it wants something different" (quoted in Khan, 2015b). This statement resonated with his stance that Greece must be willing to 'help itself' and meet the obligations set out in the memorandum in order to receive continued aid.

When the referendum was announced in late June 2015, Tsipras informed the Greek people in a television broadcast that they would have a say on the revised agreement. Within this turbulent context, he continued to frame the existing bailout agreement as a violation of "the European rules and the basic rights to work, equality and dignity" (quoted in Collins and Lynch, 2015). Reinforcing the injuries being inflicted on Greece, he also asserted that some of the "partners and institutions" sought to achieve "possibly the humiliation of an entire people" (quoted in Collins and Lynch, 2015). The frayed relationship between Athens and its creditors was reflected in the German Chancellor's reply. Outlining the concessions made by the Troika, Merkel maintained that "we have been accommodating", it was now up to Greece "to make a similar step in our direction" (quoted in Collins and Lynch, 2015). In the week of campaigning 
before the referendum vote, however, Tsipras still urged a large crowd gathered for a political rally in Athens to vote 'No' and thereby take a "stand against 'those that terrorise you'" (quoted in Bolton, 2015). By invoking injurious speech in this context, Syriza was able to stand up to the Troika and restage the 'Grexit' crisis as a mode of active resistance rather than another humiliating defeat.

That said, the injurious speech that Syriza adopted to stand up to the Troika throughout their negotiations complicated the prospect for any 'honest compromise' materialising in July 2015. Pessimistic onlookers openly predicted that the outcome of the Greek referendum constituted the final tipping point in favour of 'Grexit'. Capturing this sentiment, The Telegraph reported that Tsipras had "unilaterally ended" the chance of a rescue deal (Holehouse and Khan, 2015; see also Cendrowicz et al., 2015; The Economist, 2015). Elsewhere Jeroen Dijsselbloem, the Dutch finance minister, maintained that "this result is very regrettable for the future of Greece. For recovery of the Greek economy, difficult measures and reforms are inevitable." (quoted in Hope et al., 2015b). Adopting a more apocalyptic outlook, Mujtaba Rahman stressed that "this could mark the point of no return. Greece and the euro have now entered totally unchartered waters" (quoted in Hope et al., 2015b).

Furthermore, the language of 'suicide' was used by all parties to describe the consequences of Greece voting either way in the referendum. The Syriza government framed a 'Yes' vote as suicide for Greece. Conversely, its creditors maintained that a 'No' vote would be the equivalent of Greece committing suicide. Speaking to the Greek people, President of the European Commission Jean-Claude Juncker emphasised, "there is no need to commit suicide because you are afraid of dying. You have to vote 'Yes', whatever the question put to you [...]" (Juncker, 2015). This disjuncture between the Syriza government and the Troika on the referendum vote attests to the (counter)performatives of injurious speech in play. For at this stage of the 'Grexit' crisis, the emphasis was no longer on preventing a showdown between Athens and Brussels, but countering the opposing narrative.

So, what might a rereading of this intense stalemate look like from a securitization or blame game perspective? If we return to securitization theory, the language of 'suicide' and 'crisis' employed with respect to the referendum appears to be emblematic of a textbook case of a powerful elite undertaking a series of securitizing moves and countermoves against their enemy 'opponent'. In this account, the Troika can be seen as making moves to frame Greece as an existential security threat to the survival of the Eurozone. By extension, they were the ones to blame if Greece committed suicide. A securitization lens can also be applied to the Syriza government's performances. Here the focus could fall on how Tsipras and his administration sought to counter-securitize the Troika by framing them as the existential threat to the survival of the drowning Greek economy. Hence cooperating with the 'institutions' would be suicide for Greece.

However, explanations that concentrate on these dynamics are useful only up to a point. If the contestations that we have documented between the Troika and the Syriza government were simply a blame game or a securitizing strategy, the discursive shift towards an agreement in August 2015 is somewhat puzzling. In a nutshell, compromise and cooperation are not part of the explanatory mix found in either story. As a result, they cannot explain why Greece did not go over "the Grexit cliff" (Spiegel, 2015d). The next section attempts to make sense of the deeper levels of discursive transitivity operating in the Greek sovereign debt crisis by illustrating how injurious speech acts misfire, fail and return to speakers in ways they do not always anticipate. 


\section{Negotiating a compromise rather than 'Grexit'}

In the build-up to the Greek referendum, it is possible to discern a slight softening of the tone taken by some members of the European delegation towards their Syriza counterparts. Notably, the French Economy Minister, Emmanuel Macron, stressed that "Europe should not crush an entire people" (Cendrowicz, 2015). He also cautioned against punitive measures if the 'No' vote won. As we have already seen, this logic did not resonate well with the hard-line creditors after the snap referendum and the popular 'No' vote. Moreover, a real problem enveloping the final negotiations was that Syriza had wielded injurious speech extremely effectively to counter the bailout agreements tabled by the Troika at various stages of the negotiations. This made it very difficult for a compromise to be reached. In essence, each side had much to lose as they entered into an intense round of deliberation in July 2015. For the Troika, a compromise at this stage of the deliberations seemed to be barely conceivable, since it could mean accepting they were responsible for drowning the Greek economy through 'liquid asphyxiation' and 'fiscal water-boarding'. As the Greek sovereign debt crisis gathered momentum, the question the institutions confronted became less about whether 'Grexit' was possible and more about whether they wanted to be held responsible for the fatal demise of the European project by forcing Greece to leave against its will (Inman et al., 2015). Compromise was an equally unsatisfactory prospect for the Syriza government. In light of the referendum outcome, it would be extremely difficult for them to justify making any kind of concession to the 'terrorising' creditors who now sat across the table.

The reputational costs at stake for both camps were made apparent in the severe stalemate that followed a crucial meeting in Brussels in July $2015 .{ }^{6}$ As on and off the record reports later verified, the final round of negotiations was marred by enormous hostilities between Greece and Germany. As the President of the European Council, Donald Tusk, actively worked in the final hours to resolve the months of hostility built up between Greece and their creditors, 'Grexit' nearly became a reality (Chassany et al., 2015). After almost seventeen hours of talks, Jean-Claude Juncker conceded, "The past six months have been difficult [...] together, we have looked into the abyss. But today, I am glad to say that all sides have respected their commitments" (quoted in Alderman and Kitsantonis, 2015).

Although a new, complex, three-year bailout agreement was finally reached on 20 August 2015, it is difficult to identify a clear winner emerging from the 'Grexit' crisis. The negotiations certainly strained the fabric of the European project to its core (see Dejevsky, 2015). The approval of a third bailout deal came at an especially high price for the Syriza government. Although couched in very careful language, this summit closed with Tsipras agreeing to immediately implement a series of sweeping austerity measures and economic reforms (Wearden, 2015). As he later conceded, the dramatic shift in the Greek stance was "a necessary choice" to stave off the financial collapse of this country. In a televised address, the Prime Minister went on to remark,

I wish to be fully frank with you. We did not achieve the agreement that we were hoping for. But [the agreement] was the best anyone could have achieved. We are obliged to observe it - but at the same time we will do our utmost to minimise its negative consequences. (quoted in Henley and Traynor, 2015)

Evidently this admission did not shield him from accusations of bowing to "Eurozone dictatorship" at home (Chan, 2015). Making his dissatisfaction plain, Lafazanis branded the agreement "unacceptable [...] Our so-called partners led by the German establishment, behaved towards our country as being their colony and they are nothing more than brutal blackmailers and financial assassins" (quoted in Foy et al., 2015). 
Mounting dissent and animosity made it difficult for Tsipras to push the new bailout agreement through the Greek parliament to keep their country in the Eurozone. In the political aftermath, he tried to reassure legislators that,

Conservative forces within Europe still insist on their plans to kick Greece out of the euro [...] We chose a compromise that forces us to implement a program we don't believe in and we will implement it, because the choices we have are tough. (Chrepa and Chrysoloras, 2015)

Such candid remarks did not prevent the Syriza party from splitting. In a strong act of rebellion, dissidents formed another party, Popular Unity, headed by the former Energy Minister, Panagiotis Lafazanis. The dual mandate of this new party was to overhaul the terms of the third bailout agreement and openly embrace a return to the drachma (Galbraith, 2016: 181; Henley and Traynor, 2015). Claiming ownership of the injurious speech that Syriza had executed so successful to talk back to the Troika, Lafazanis explained,

The country cannot take more bailouts. We will either finish off the bailouts, or the bailouts will finish off Greece and the Greek people. The country cannot breathe and stand on its feet unless a big part of the debt is cancelled. (quoted in Henley and Traynor, 2015)

This restaging of the language of 'asphyxiation', 'drowning' and 'fiscal waterboarding' offers a glimpse of the performative power of injurious speech. It also attests to Butler's notion of discursive transitivity. In effect, the creation of Popular Unity halted the ability of Tsipras and his supporters to claim complete ownership over injurious terms to counter the third bailout programme.

The Syriza government that remained intact also encountered enormous hurdles on the international stage. In a blow to Athens, the new bailout agreement postponed moves to writeoff some of Greece's debt until October 2015. Given the dismal state of the Greek economy in the aftermath of five weeks of capital controls, this pregnant pause in the deliberations was severely problematic (Rankin, 2015). Adding another level of concern, the IMF openly refused to participate in another bailout programme unless it received an "explicit and concrete agreement" on debt relief for Greece from its partners (Rankin, 2015). This stance was significant since it raised enormous uncertainty over who would fund the final bailout deal.

The dominant perception is that Tsipras buckled under the enormous pressure placed on him at the crisis summit in Brussels in July 2015. Arguably the weight of this enormous defeat, coupled with the revolt by hardliners in his government, accounts for his decision to step down to pave the way for snap elections held on 20 September 2015 (Henley and Traynor, 2015). There is something to this storyline, but there are problems too. First, Tsipras resigned after the tough bailout agreement had already passed through parliament. As such, he had already managed to tentatively bridge one of the thorniest bailout rifts. Second, his resignation came within hours of his country receiving its first tranche of the new bailout funds, allowing it to make a critical €3.4bn debt repayment to the ECB (Galbraith, 2016; Henley and Traynor, 2015). Moreover, and most importantly, Tsipras never expressed regret about choosing compromise. How did he manage to do this? What allowed Tsipras to credibly restage the newly agreed deal in 2015?

Paradoxically, it is at precisely this point that we find one of his most dramatic performances of injurious speech. Although the presence of rival voices and the passing of an extremely unpopular agreement now complicated this bargaining strategy, Tsipras attempts to restage the language of 'suicide', 'asphyxiation' and 'fiscal waterboarding'. After the 2015 negotiations in Brussels onwards, he maintains that rejecting this deal would have been the 
equivalent of Greece committing suicide (Alderman and Kitsantonis, 2015). This discursive shift produces a rather unexpected scenario. To forge a consensus at the national and international level, Tsipras has to abandon the battleground of blame and securitization. In the process, he had to initiate a new set of performatives that discursively constructed the 2015 agreement as the only available option for resuscitating the drowning Greek economy. Hence, rather than try to carve out a strict boundary between words that wound and those that do not, the Greek sovereign debt crisis seems to suggest that these types of performatives and 'overflowings' are always unfixed and unfixable. In this spirit, we conclude with an invitation for critical scholars to continue to reflect on how words wound in ambiguous ways.

\section{Conclusion}

This article has adopted Butler's notion of injurious speech, using it to conceptualise the negotiations that took place between Syriza and the Troika as a series of discursive performatives and situated entanglements. A cursory view of the discourses adopted by Tsipras and his government illustrates that they were attempting to do more than simply blame the Troika of drowning the Greek economy through a policy of 'fiscal waterboarding', 'asphyxiation' and 'suicide'. On a closer reading, this article has found that the Syriza government actively used injurious speech to construct a forceful counter-narrative with which they could speak back to the Troika. Understood as such, one can argue that this linguistic strategy empowered them to ritualistically restage Greece's financial woes as a question of national sovereignty and survival rather than humiliating defeat.

However, Butler's conceptualisation of injurious speech invites us to reflect on how words misfire and wound in unpredictable ways. Taking stock of the complex series of negotiations that unfolded between January and August 2015, it is plain that the injurious speech acts performed by Syriza were returned to them in ways they did not anticipate. This is most powerfully demonstrated by the new bailout agreement that came into effect in August 2015. Despite their repeated promises 'to stop Greece bleeding', the Syriza government ultimately agreed to a new three-year bailout agreement in July 2015 that many claimed would prolong the suffering of the country. On this premise alone, it is possible to argue that the bargaining strategy pursued by Tsipras and his government misfired. In a similar vein, the intense crisis summit that took place in Brussels in July 2015 can be read as proof that their accusations of 'fiscal waterboarding', 'asphyxiation' and 'suicide' eroded the trust of their international creditors to a point that compromise became almost impossible to achieve. Going further, one could even speculate that the injurious counter-speech employed by Syriza provided the Troika with an alibi for taking such a tough stance towards Greece in the final terms and conditions of the new bailout agreement.

Yet our analysis has shown that there is a far more interesting set of performances at play. The dominant narrative that emerged from the 2015 negotiations between Syriza and the Troika is one of compromise. This aspect has received little attention in those studies that foreground the dynamics of blame and securitization at play during the Greek sovereign debt crisis. As we have shown, the discursive shift away from injurious speech towards the language of compromise could only be accomplished when both sides restaged their bargaining positions. The concessions made by Syriza and the Troika exhibit a mutual recognition that Greece exiting the Eurozone would be painfully counterproductive. Retrospectively, they also add weight to Varoufakis's claim that the euro was a fragile house of cards that could be undone if the Greek card was pulled away. 
As to whether Greece will manage to avoid a default in the future, the jury is still out. At present, the prospect of another 'Grexit' crisis materialising is considered to be extremely unlikely. On 15 June 2017, Greece and its international creditors reached a deal that secured the next tranche of $€ 8.5 \mathrm{bn}(£ 7.4 \mathrm{bn})$ bailout funds. In the immediate term, this deal has removed months of uncertainty over whether Greece would be capable of meeting its next debt repayment (Brunsden, 2017). By extension, the latest agreement has ensured that Greece did not default on its outstanding debt obligations in July 2017.

While these outcomes have been celebrated by Dijsselbloem as a "major step forwards" (quoted in Brunsden, 2017), there are many other factors at play. For the average person, the third bailout programme that Syriza signed up to in July 2015 translated into a series of tough reform measures, including major cuts to pensions and a reassessment of Greece's income tax system. In a letter penned to the Financial Times on 16 February 2017, Effie Achtsioglou, the Minister of Labour, Social Security and Social Solidary warned that "insisting on further pension cuts while Greek pensioners barely have enough to live on is definitely not the way to go to address public discontent" (Achtsioglou, 2017). Dissatisfaction with the country's austerity programme is not limited to the implementation of a new pension law in 2016. Reports indicate that thousands of people protested and clashed with riot police during a demonstration on 15 November 2016, when then US President Barack Obama paid a state visit to Greece (Smith, 2016). As Dimitris Christopoulos (2016) correctly noted, "all this has shaken the already turbulent Greek political scene". In June 2017, fresh strike action over rubbish collection erupted on the streets of Athens, when "thousands of public sector workers" demonstrated and clashed with police (Monaghan, 2017).

Another tension that has not been resolved by the June 2017 bailout programme relates to what counts as sustainable debt relief and debt forgiveness for Greece (Brunsden, 2017). Visible rifts between the IMF and the ECB on these issues have become increasingly apparent in the latest round of negotiations. These disagreements suggest that the Troika is not presenting a unified voice when it comes to putting the Greek economy on sounder footing (Brunsden, 2017). A key finding of a recent report, IMF and the Eurozone Crises, was that the decision to provide Greece with financial support in 2010 did not follow IMF policy. Going further, this document (which was produced by the IMF's Independent Evaluation Office), stated that the decision was made without sufficient analysis of the "adverse consequences of not restructuring debt" (Independent Evaluation Office of the International Monetary Fund, 2016). Against this backdrop, the June 2017 agreement resulted in the qualified participation of the IMF, subject to “Greece's European creditors providing commitments for debt relief sufficient to secure debt sustainability" (Lagarde, 2017; see also, Smith, 2017b). The growing acrimony characterising the standoff between the IMF, the ECB and the EC demonstrates that a focus on injurious speech may have broader implications for studying contested negotiations between international creditors and institutions and domestic political parties. ${ }^{7}$

A final question mark lingering over the Greece sovereign debt crisis is whether Tsipras and his government can continue to restage the language of injury they levelled against the Troika. Commenting on the 15 June 2017 Eurogroup statement, Varoufakis returned to the analogy of a drowning economy. As he noted, "it is like a lifesaver tying a ball-in-chain on the leg of a weakened swimmer, throwing him back into deep waters, and then inviting him to "develop and support a holistic buoyancy-enhancing strategy, including improvements in the swimming climate'" (Varoufakis, 2017). It is easy to dismiss this line of argument as another type of blame game. Following this logic, the former finance minister is simply criticising Tsipras and the 2017 bailout package from the sidelines. One might add that his arguments exaggerate the lingering dangers confronting the Greek economy, as it continues to secure 
debt relief and regain access to financial markets (Moore, 2015). ${ }^{8}$ Invoking Butler, we cannot say with any certainty that any of these accounts are complete. Nevertheless, Varoufakis's commentary reminds us that the language of a 'drowning economy' is still in play. As such, we cannot be quite as sanguine in holding injurious speech to be of peripheral concern for the Syriza government or anyone interested in the ongoing negotiation of the Greek sovereign debt crisis. Rather, as Butler reminds us, there is much to think about when we contemplate how words injure, misfire and fail. Hence, we contend that the concept of injurious speech should be incorporated into the rapidly expanding research programmes on performativity and counter-performativity in economics.

\section{Acknowledgments}

We would like to thank Max Cohen, Lin Alexandra Mortensgaard, and Katarina Rebello for their excellent research assistance in this project. We are also grateful to Hilda McNae for the time and support that she dedicated to this research, especially at the outset. Lastly, we would like to thank the editors and our reviewers. Their comments and guidance helped us to clarify our arguments and make the article better. The standard disclaimers apply regarding any remaining faults and oversights in the final article.

\section{Notes}

1. The 'Troika' consists of the International Monetary Fund (IMF), the European Central Bank (ECB) and the European Commission (EC). This group was later identified as 'the institutions' as a way of avoiding the negative connotations that developed around the word 'Troika'.

2. The Wall Street Journal maintains a timeline for Greek government debt by due date and holder. See: <http://graphics.wsj.com/greece-debt-timeline/>.

3. We would like to thank one of the reviewers for asking us to engage with the security studies literature on securitization. While the main goal of this article is not to adopt a securitization framework, we welcome this comment as it has helped us to think about potential overlaps and differences between Butler's concept of injurious speech and securitization theory. We will certainly take these ideas away with us for future projects. For now, readers who are interested in securitization and counter-securitization processes are directed to the extant literature on this (Balzacq, 2015; Stritzel and Chang, 2015; Vuori, 2015; Bourbeau and Vuori, 2015). There are also a number of works that deal specifically with securitization in the economic sphere (Aitken, 2007; de Goede, 2010, 2015; Langenohl, 2017).

4. In line with the previous note of guidance from our reviewers (en. 3), further research may be needed to explore whether the outcome of the Grexit crisis constitutes a case of desecuritization or resecuritization, rather than the continuation of familiar securitizing moves.

5. In his critique of Callon's account of performativity, MacKenzie (2008: 19) distinguishes between 'generic' and 'Austinian' performativity.

6. For excellent accounts of the reputational cost that can be narrated during a crisis, see the work of Janice Bially Mattern (2005; 2001).

7. We would like to thank one of the reviewers for bringing this comparative angle to our attention. In the context of the Eurozone crisis, it would be worth examining if injurious speech was invoked by Cyprus, Portugal, Italy, Spain or Ireland to speak back to the Troika. Taking a more global perspective, Argentina and Puerto Rico may also provide rich empirical sites to excavate.

8. Since the time of writing, Greece has been successful in selling sovereign debt on international financial markets. See, for example, Hale (2017) and Smith (2017a). 


\section{References}

Achtsioglou, E. (2017) Greece's pensioners already have barely enough to live on. Financial Times, 16 February.

Adler-Nissen, R. (2017) Are we 'Nazi Germans' or 'Lazy Greeks'? Negotiating international hierarchies in the Euro crisis. In Zarakol, A. (ed.) Hierarchies in World Politics. Cambridge: Cambridge University Press, 198-218.

Aitken, R. (2007) Performing Capital: Toward a Cultural Economy of Popular and Global Finance. Basingstoke: Palgrave Macmillan.

Alderman, L. and Kitsantonis, N. (2015) Bailout package passes amid dissent in Athens. New York Times, 15 August.

Anderson, E. (2015) German finance chief Wolfgang Schaeuble softens tough tone against Greece. The Telegraph, 1 March.

Ardagna, S. and Caselli, F. (2014) The political economy of the Greek debt crisis: A tale of two bailouts. American Economic Journal: Macroeconomics, 6(4): 291-323.

Aslanidis, P. and Marantzidis, N. (2016) The impact of the Greek indignados on Greek politics. Southeastern Europe, 40(2): 125-57.

Åtland, K. and Ven Bruusgaard, K. (2009) When security speech acts misfire: Russia and the Elektron incident. Security Dialogue, 40(3): 333-53.

Austin, J.L. (1975) How to Do Things with Words: The William James Lectures delivered at Harvard University. Oxford: Claredon Press.

Ayiomamitis, P. (2015) We must hold our heads up high and not succumb to blackmail. The Independent, 21 February.

Balzacq, T. (ed) (2015) Contesting Security: Strategies and Logics. Abingdon: Routledge.

BBC News (2014) Greece crisis: Germany's Schaeuble warns over reform. BBC News, 30 December. Available at: <http://www.bbc.com/news/world-europe-30629269/>. Accessed 19 November 2016.

BBC News (2015) Greek debt 'illegal, illegitimate and odious'. BBC News, 18 June. Available at: <http://www.bbc.co.uk/news/world-europe-33179593/>. Accessed 15 March 2016.

Bolton, D. (2015) Alexis Tsipras speaks to 25,000 at 'No' rally in Syntagma Square, urging voters to deny 'those who terrorise you'. The Independent, 3 July.

Bourbeau, P. and Vuori, J.A. (2015) Security, resilience and desecuritization: Multidirectional moves and dynamics. Critical Studies on Security, 3(3): 253-68.

Brunsden, J. (2017) Greece bailout deal met with relief as default is averted. Financial Times, 16 June.

Butler, J. (1993) Bodies that Matter: On the Discursive Limits of 'Sex'. London: Routledge.

Butler, J. (1997) Excitable Speech: A Politics of the Performative. London: Routledge.

Butler, J. (2010) Performative agency. Journal of Cultural Economy, 3(2): 147-61.

Callon, M. (2007) What does it mean to say that economics is performative? In MacKenzie, D., Muniesa, F. and Siu, L. (eds.) Do Economists Make Markets? On the Performativity of Economics. Princeton, NJ: Princeton University Press, 311-57.

Callon, M. (2010) Performativity, misfires and politics. Journal of Cultural Economy, 3(2): 163-69.

Cendrowicz, L. (2015) Eurozone holds out an olive branch of more negotiation. The Independent, 6 July. Cendrowicz, L., Johnston, I. and Savaricas, N. (2015) Greece referendum: Greeks say ‘No' to austerity and plunge Europe into crisis. The Independent, 6 July.

Chan, S.P. (2015) Greece on verge of clinching new bail-out but lenders delay debt talks until October. The Telegraph, 14 August.

Chassany, A.-S., Barker, A. and Robinson, D. (2015) Greece talks: 'Sorry but there is no way you are leaving this room'. Financial Times, 13 July. 
Chrepa, E. and Chrysoloras, N. (2015) Greek PM Alexis Tsipras appeals to siege mentality to clinch bailout vote. Financial Post, 23 July. Available at:

$<$ http://business.financialpost.com/news/economy/greek-pm-alexis-tsipras-appeals-to-siegementality-to-clinch-bailout-vote/>. Accessed 11 December 2016.

Christopoulos, D. (2016) Greece still has political life beyond austerity. But what kind of life is it? openDemocracy, 17 November. Available at: <https://www.opendemocracy.net/can-europe-makeit/dimitris-christopoulos/greece-has-still-political-life-beyond-austerity-but-what-/>. Accessed 25 June 2017.

Collins, S. and Lynch, S. (2015) Tsipras calls referendum on bailout. The Irish Times, 26 June. Available at: <http://www.irishtimes.com/news/world/europe/tsipras-announces-referendum-will-be-heldon-greek-bailout-1.2264539/>. Accessed 28 March 2016.

de Goede, M. (2010) Financial security. In Burgess, J.P. (ed.) The Routledge Handbook of New Security Studies. London: Routledge, 100-09.

de Goede, M. (2015) Speculative values and courtroom contestations. South Atlantic Quarterly, 114(2): 355-75.

de Goede, M., Simon, S. and Hoijtink, M. (2014) Performing preemption. Security Dialogue, 45(5): 41122.

Dejevsky, M. (2015) Grexit may have been avoided, but divisions in Europe are growing. The Guardian, 13 July. Available at: <https://www.theguardian.com/commentisfree/2015/jul/13/grexit-europegreece-deal-eu/>. Accessed 11 December 2016.

Donadio, R. and Kitsantonis, N. (2011) Greek leader calls off referendum on bailout plan. New York Times, 3 November. Available at: <http://www.nytimes.com/2011/11/04/world/europe/greekleaders-split-on-euro-referendum.html/>. Accessed 14 November 2016.

Economist, The (2015) Athenians at bay. The Economist, 27 June.

Ertel, M., Kuntz, K. and von Rohr, M. (2015) SPIEGEL Interview with Greek Prime Minister Tsipras: 'We don't want to go on borrowing forever'. Der Spiegel, 7 March. Available at: <http://www.spiegel.de/international/europe/spiegel-interview-with-greek-prime-minister-tsiprasa-1022156.html/>. Accessed March 2016.

Esposito, E. (2013) The structures of uncertainty: Performativity and unpredictability in economic operations. Economy and Society, 42(1): 102-29.

Evans-Pritchard, A. (2015a) Germany faces impossible choice as Greek austerity revolt spreads. The Telegraph, 12 February.

Evans-Pritchard, A. (2015b) Greece's rock-star finance minister Yanis Varoufakis defies ECB's drachma threats. The Telegraph, 3 February.

Evans-Pritchard, A. (2015c) Greece averts bankruptcy and softens austerity in last-ditch deal. The Telegraph, 20 February.

Evans-Pritchard, A. (2015d) Greek defiance mounts as Alexis Tsipras turns to Russia and China. The Telegraph, 2 April.

Evans-Pritchard, A. (2015e) Grexit dangers mount as Greece's Yanis Varoufakis warns of 'liquidity asphyxiation'. The Telegraph, 17 April.

Featherstone, K. (2011) The Greek sovereign debt crisis and EMU: A failing state in a skewed regime. Journal of Common Market Studies, 49(2): 193-217.

Financial Times (2015a) Greece's Syriza and Europe must be patient and pragmatic. Financial Times, 27 February.

Financial Times (2015b) Syriza's electoral win is a chance to strike a deal. Financial Times, 27 January.

Forelle, C. (2015) The alternative Davos agenda: Greek elections and Eurozone woes. Wall Street Journal, 21 January. Available at: <http://www.wsj.com/articles/the-alternative-davos-agenda1421777054/>. Accessed 17 November 2016. 
Foy, H., Spiegel, P. and Wagstyl, S. (2015) Greece's Alex Tsipras faces Syriza rebellion over 'humilitation'. Financial Times, 14 July.

Galbraith, J.K. (2016) Welcome to the Poisoned Chalice: The Destruction of Greece and the Future of Europe. New Haven, CT: Yale University Press.

Georgakopoulou, A. (2014) Small stories transposition and social media: A micro-perspective on the 'Greek crisis'. Discourse and Society, 25(4): 519-39.

Hale, T. (2017) National Bank of Greece plots new bond in latest sign of country's rebound. Financial Times, 3 October.

Henley, J. and Traynor, I. (2015) Greek crisis: Syriza rebels form Popular Unity party ahead of election. The Guardian, 21 August. Available at:

<https://www.theguardian.com/world/2015/aug/21/greek-crisis-syriza-rebels-break-away-formpopular-unity-party/>. Accessed 11 December 2016.

Holehouse, M. and Khan, M. (2015) Greece just days away from fatal eurozone rupture as creditor powers poised to pull the plug. The Telegraph, 28 June.

Hope, K., Aglionby, J. and Moore, E. (2015a) Tsipras talks tough over Greek bailout terms. Financial Times, 28 January.

Hope, K., Foy, H. and Wagstyl, S. (2015b) Greece's eurozone future in doubt after decisive No victory. Financial Times, 5 July.

Independent Evaluation Office of the International Monetary Fund (2016) The IMF and the Crises in Greece, Ireland, and Portugal. Washington, DC: International Monetary Fund. Available at: <http://www.ieo-imf.org/ieo/pages/CompletedEvaluation267.aspx/>. Accessed 29 July 2016.

Inman, P., Smith, H. and Wearden, G. (2015) Greek exit would trigger eurozone collapse, says Alexis Tsipras. The Guardian, 9 June. Available at: <https://www.theguardian.com/business/2015/jun/09/greek-exit-would-trigger-eurozonecollapse-says-alexis-tsipras/>. Accessed 11 December 2016.

Jacobides, M.G. (2015) What Greece has to do now: Fix its economy. Harvard Business Review, 27 February. Available at: <https://hbr.org/2015/02/what-greece-has-to-do-now-fix-its-economy/>. Accessed 20 October 2016.

Jamieson, S. (2015) Alexis Tsipras: 'I'm ready for honest compromise'. The Telegraph, 12 July. Available at: <http://www.telegraph.co.uk/finance/economics/11734647/Alexis-Tsipras-Im-ready-forhonest-compromise.html/>. Accessed 20 March 2016.

Juncker, J.-C. (2015) Transcript of President Jean-Claude Juncker's press conference on Greece. Brussels, European Commission, 29 June 2015. Available at: <http://europa.eu/rapid/pressrelease_SPEECH-15-5274_en.htm/>. Accessed 20 March 2016.

Karyotis, G. and Rüdig, W. (2015) Blame and punishment? The electoral politics of extreme austerity in Greece. Political Studies, 63(1): 2-24.

Khan, M. (2015a) Europe holds 'noose around Greek necks' as Athens scrambles to make debt payments. The Telegraph, 6 March.

Khan, M. (2015b) Germany says 'helpful' referendum could decide Greece's euro fate. The Telegraph, 11 May.

Khan, M. (2015c) Greco-German relations reach breaking point as ECB warned to stop 'asphyxiating' Athens. The Telegraph, 12 March.

Khan, M. (2015d) 'Greece will not bow down to blackmail'. The Daily Telegraph, 30 April.

Khan, M. (2015e) Tsipras vows to ‘stop Greeks bleeding'. The Daily Telegraph, 31 March.

Lagarde, C. (2017) IMF Managing Director Christine Lagarde to propose approval in principle of new stand-by arrangement for Greece. IMF Press Release No. 17/225. Available at: <http://www.imf.org/en/News/Articles/2017/06/15/pr17225-imf-lagarde-to-propose-approval-inprinciple-of-new-stand-by-arrangement-for-greece/>. Accessed 25 June 2017. 
Langenohl, A. (2017) Securities markets and political securitization: The case of the sovereign debt crisis in the Eurozone. Security Dialogue, 48(2): 131-48.

Langley, P. (2015) Liquidity Lost: The Governance of the Global Financial Crisis. Oxford: Oxford University Press.

MacKenzie, D. (2004) The big, bad wolf and the rational market: Portfolio insurance, the 1987 crash and the performativity of economics. Economy and Society, 33(3): 303-34.

MacKenzie, D. (2007) Globalisation, efficient markets, and arbitrage. In: Assassi, L., Nesvetailova, A. and Wigan, D. (eds.) Global Finance in the New Century: Beyond Deregulation. Basingstoke, Palgrave Macmillan, 13-24.

MacKenzie, D. (2008) An Engine, Not a Camera: How Financial Models Shape Markets. Cambridge, MA: MIT Press.

Mackenzie, D. and Millo, Y. (2003) Constructing a market, performing theory: The historical sociology of a financial derivatives exchange. American Journal of Sociology, 109(1): 107-45.

Mattern, J.B. (2001) The power politics of identity. European Journal of International Relations, 7(3): 349-97.

Mattern, J.B. (2005) Ordering International Politics: Identity, Crisis, and Representational Force. London: Routledge.

Monaghan, A. (2017) Athens: Thousands of public-sector workers march against austerity. The Guardian, 22 June. Available at: <https://www.theguardian.com/world/2017/jun/22/greeceathens-public-sector-workers-march-austerity-rubbish-collection/>. Accessed 22 June 2017.

Moore, E. (2015) Greece recovery depends on market access. Financial Times, 3 July.

Moschella, M. (2016) Negotiating Greece: Layering, insulation, and the design of adjustment programs in the Eurozone. Review of International Political Economy, 23(5): 799-824.

Muniesa, F. (2014) The Provoked Economy: Economic Reality and the Performative Turn. London: Routledge.

Nikolakakis, N. (2016) Syriza's stance vis-à-vis the European Union following the financial crisis: The persistence of left Europeanism and the role of the European Left party. European Politics and Society, 18(2): 128-47.

Papamiltiadou, A. (2015) Tsipras: Referendum if debt deal crosses 'red lines'. Market News International, 27 April. Available at: <https://www.marketnews.com/content/update-tsiprasreferendum-if-debt-deal-crosses-red-lines/>. Accessed 12 March 2016.

Paterson, T. and Savaricas, N. (2015) Greek Prime Minister Alexis Tsipras won't give in to 'blackmail' over bailout reforms. The Independent, 17 February.

Petrakis, M. (2015) Setbacks for Tsipras stir discord in Greek ruling party. Bloomberg, 26 February. Available at: <http://www.bloomberg.com/news/articles/2015-02-26/tsipras-reversal-drawsgreek-sympathy-as-party-rumblings-rise/>. Accessed 17 November 2016.

Rankin, J. (2015) Tsipras: Greece on 'final stretch' of talks with creditors over bailout deal. The Guardian, 5 August. Available at: <https://www.theguardian.com/world/2015/aug/05/tsiprasgreece-final-stages-bailout-deal-talks/>. Accessed 10 December 2016.

Roscoe, P. (2016) Performativity matters: Economic description as a moral problem. In: Boldyrev, I. and Svetlova, E. (eds.) Enacting Dismal Science: New Perspectives on the Performativity of Economics. Basingstoke: Palgrave Macmillan, 131-50.

Selmic, R. (2016) The European Central Bank, machinic enslavement, and the Greek public sector. Finance and Society, 1(2): 45-61.

Sheffield, H. (2015) Greece crisis: Tsipras rails against attempts to ‘humiliate’ government. The Independent, 17 June.

Smith, H. (2016) Barack Obama raises possibility of debt relief on final Greece visit. The Guardian, 15 November. 
Smith, H. (2017a) The eurozone may be back on its feet. But is Greece? The Guardian, 16 September. Available at: <https://www.theguardian.com/world/2017/sep/16/eurozone-back-on-its-feet-butwhat-about-greece/>. Accessed 16 September 2017.

Smith, H. (2017b) Creditors agree terms to disburse Greece's $€ 8.5 b n$ bailout funds. The Guardian, 15 June. Available at: <https://www.theguardian.com/world/2017/jun/16/creditors-agree-terms-todisburse-greeces-85bn-bailout-funds/>. Accessed 25 June 2017.

Spiegel, P. (2015a) Greece's leader warns Merkel of ‘impossible’ debt payments. Financial Times, 22 March.

Spiegel, P. (2015b) Lack of trust hampers race to salvage Greece bailout deal. Financial Times, 17 February.

Spiegel, P. (2015c) Tsipras accuses bailout monitors of making 'absurd' demands. Financial Times, 31 May.

Spiegel, P. (2015d) Year in a word: Oxi. Financial Times, 23 December.

Spiegel, P. and Hope, K. (2015) Greek default fears rise as '11th hour' talks collapse. Financial Times, 14 June.

Spiegel, P. et al. (2015a) Juncker accuses Athens of misleading Greek people. Financial Times, 17 June.

Spiegel, P. et al. (2015b) Germans rebuff Greek ‘Trojan horse'. Financial Times, 19 February.

Stamouli, N. (2017) Greece: A case study in capital controls. Wall Street Journal, 15 June. Available at: <https://www.wsj.com/articles/greece-a-case-study-in-capital-controls-1497519001/>. Accessed 24 June 2017.

Stavrakakis, Y. and Katsambekis, G. (2014) Left-wing populism in the European periphery: The case of Syriza. Journal of Political Ideologies, 19(2): 119-42.

Stevenson, C. (2015) Greek bailout: Alexis Tsipras heralds euro debt reprieve but says real difficulties are still ahead. The Independent, 22 February.

Stritzel, H. and Chang, S.C. (2015) Securitization and counter-cecuritization in Afghanistan. Security Dialogue, 46(6): 548-67.

Theodossopoulos, D. (2013) Infuriated with the infuriated? Blaming tactics and discontent about the Greek financial crisis. Current Anthropology, 54(2): 200-21.

Trotman, A. (2015) Greece 'will not play ball with Troika creditors'. The Telegraph, 31 March.

Varoufakis, Y. (2012) Fiscal waterboarding versus Eurobonds: Misrepresenting the latter to effect the former. 24 May. Available at: <https://yanisvaroufakis.eu/2012/05/24/fiscal-waterboardingversus-eurobonds-misrepresenting-the-latter-to-effect-the-former/>. Accessed 24 August 2016.

Varoufakis, Y. (2017) The annotated 15th June 2017 Eurogroup statement on Greece. Available at: <https://www.yanisvaroufakis.eu/2017/06/16/the-annotated-15th-june-2017-eurogroupstatement-on-greece/>. Accessed 23 June 2017.

Vuori, J.A. (2015) Contesting and resisting security in post-Mao China. In: Balzacq, T. (ed.) Contesting Security: Strategies and Logics. Abingdon: Routledge, 29-43.

Wagstyl, S. and Bryant, C. (2015) Greeks expected to reject austerity but Germans will not consider debt relief. Financial Times, 24 January.

Walker, M. (2015) Greece's challenge: Appeasing its creditors and its population. Wall Street Journal, 27 February. Available at: <http://www.wsj.com/articles/greeces-challenge-appeasing-itscreditors-and-its-population-1424988476/>. Accessed 19 November 2016.

Wearden, G. (2015) Greece bailout agreement: Key points. The Guardian, 13 July. Available at: <https://www.theguardian.com/business/2015/jul/13/greece-bailout-agreement-key-pointsgrexit/>. Accessed 11 December 2016.

Wearden, G. and Fletcher, N. (2015) Tsipras says summit positive for Greece, will get EU funds. The Guardian, 20 March. 
Welfens, P.J.J. (2016) Overcoming the euro crisis and prospects for a political union. International Economics and Economic Policy, 13(1): 59-103.

Wodak, R. and Angouri, J. (2014) From Grexit to Grecovery: Euro/crisis discourses. Discourse and Society, 25(4): 417-23.

Yardley, J., Bounias, D. and Kitsantonis, N. (2015) Greece's new left-wing cabinet signals willingness to confront EU over policies. New York Times, 28 January. 